University of Nebraska - Lincoln

DigitalCommons@University of Nebraska - Lincoln

\title{
Seasonal Changes in Shoot and Root Nitrogen Distribution in Switchgrass (Panicum virgatum)
}

\author{
Sandra Wayman \\ Washington State University, Sandra.Wayman@email.wsu.edu \\ Richard D. Bowden \\ Allegheny College, richard.bowden@allegheny.edu \\ Robert B. Mitchell \\ University of Nebraska-Lincoln, rob.mitchell@ars.usda.gov
}

Follow this and additional works at: https://digitalcommons.unl.edu/usdaarsfacpub

Wayman, Sandra; Bowden, Richard D.; and Mitchell, Robert B., "Seasonal Changes in Shoot and Root Nitrogen Distribution in Switchgrass (Panicum virgatum)" (2013). Publications from USDA-ARS / UNL Faculty. 1272.

https://digitalcommons.unl.edu/usdaarsfacpub/1272

This Article is brought to you for free and open access by the U.S. Department of Agriculture: Agricultural Research Service, Lincoln, Nebraska at DigitalCommons@University of Nebraska - Lincoln. It has been accepted for inclusion in Publications from USDA-ARS / UNL Faculty by an authorized administrator of DigitalCommons@University of Nebraska - Lincoln. 


\title{
Seasonal Changes in Shoot and Root Nitrogen Distribution in Switchgrass (Panicum virgatum)
}

\author{
Sandra Wayman • Richard D. Bowden • \\ Robert B. Mitchell
}

(C) Springer Science+Business Media New York 2013

This article is a U.S. government work, and is not subject to copyright in the United States.

\begin{abstract}
Switchgrass is a promising bioenergy source that is perennial, productive, native to a broad geographic region, and can grow on marginal, nitrogen (N)-poor soils. Understanding $\mathrm{N}$ dynamics in switchgrass is critical to predicting productivity, conserving $\mathrm{N}$, and optimizing the timing of harvest. We examined seasonal changes in $\mathrm{N}$ distribution in above- and belowground tissues in switchgrass to quantify $\mathrm{N}$ retranslocation rates. Above- and belowground biomass from three sites (two in PA and one in NE) were collected and analyzed for biomass growth and $\mathrm{N}$ concentrations at 30-day intervals from June through October. Total living plant mass ranged from 10.3 \pm 2.4 standard error (SE) to $14.9 \pm 2.5 \mathrm{SE} \mathrm{Mg} \mathrm{ha}^{-1}$. Belowground mass comprised $52-57 \%$ of total mass. Blades had the highest $\mathrm{N}$ concentration during summer, ranging from 6 to $22 \mathrm{~g} \mathrm{~kg}^{-1} \mathrm{~N}$. Aboveground $\mathrm{N}$ concentrations decreased from September until autumn senescence, whereas belowground $\mathrm{N}$ concentration increased from August until senescence. Across the sites, total $\mathrm{N}$ retranslocated from aboveground to belowground components between September and October averaged 16.5 \pm 7.1 (SE) $\mathrm{kg} \mathrm{ha}^{-1} \mathrm{~N}$ representing $26.7 \%$ of the average maximum $\mathrm{N}$ content of aboveground biomass. Based on $\mathrm{N}$ fertilizer costs, delayed harvest would conserve some $\mathrm{N}$ and provide financial savings on fertilizer $\left(\$ 9 \mathrm{ha}^{-1}\right)$ if harvest occurs after senescence but before overwinter biomass loss. However, biomass losses of even $10 \%$ will negate potential economic savings accrued from $\mathrm{N}$ retention. To maximize environmental and economic
\end{abstract}

S. Wayman

Department of Crop and Soil Sciences, Washington State University, Puyallup, WA, USA

R. D. Bowden $(\bowtie)$

Allegheny College, Department of Environmental Science, 520

North Main Street, Meadville, PA 16335, USA

e-mail: richard.bowden@allegheny.edu

R. B. Mitchell

USDA-ARS Grain, Forage and Bioenergy Research Unit, University

of Nebraska, Lincoln, NE, USA savings from $\mathrm{N}$ retranslocation and to simultaneously minimize harvest losses, it would be optimal to harvest switchgrass as soon as possible after complete senescence.

Keywords Bioenergy $\cdot$ Biofuel $\cdot$ Harvest $\cdot$ Nitrogen retranslocation $\cdot$ Panicum virgatum $\cdot$ Switchgrass

\section{Introduction}

Biomass is a promising alternative energy source because it is renewable, nearly carbon neutral, and has the potential to reduce energy-related greenhouse gas emissions [1-4]. Switchgrass (Panicum virgatum L.) is a warm-season perennial grass that is productive and nutrient-use efficient on land that is marginally productive for annual row crops $[1,3,5]$. On-farm research has demonstrated that switchgrass is more energy efficient than corn for ethanol production and that switchgrass has $94 \%$ lower greenhouse gas emissions than gasoline [2]. On non-irrigated marginal soils using similar fertilizer rates, switchgrass had greater potential ethanol yield than corn [7]. Switchgrass is projected to compete favorably with anticipated increases in prices of natural gas and crude oil [8] and can provide socioeconomic benefits especially in rural areas [9].

As a biofuel, switchgrass offers several environmental benefits. It is favorable to wildlife if habitat diversity and appropriate harvest strategies are employed [10]. The extensive root system [11, 12] of switchgrass reduces erosion [13-15] and can sequester more than $1 \mathrm{Mg} \mathrm{ha}^{-1}$ of soil carbon annually [16-21]. Switchgrass stores up to $80 \%$ of its mass belowground in the perennial root systems $[22,23]$.

Switchgrass has low nitrogen $(\mathrm{N})$ needs but responds to $\mathrm{N}$ fertilizer with increased biomass yields [5, 24, 25]. Annual removal of switchgrass requires nutrient replacement through fertilizer application. However, because $\mathrm{N}$ application is expensive and has the potential for increasing $\mathrm{N}$ emissions and 
contaminating surface and groundwater, inputs need to be managed closely [26, 27]. In a multistate study with an average $\mathrm{N}$ application of $74 \mathrm{~kg} \mathrm{ha}^{-1}$, fertilization accounted for $10 \%$ of total production costs [28]. Additionally, energy used in fertilizer manufacture and application is a major driver in the life cycle assessment of switchgrass [6, 29].

Switchgrass $\mathrm{N}$ demands are met through uptake from soil, but also from recovery of some of its aboveground $\mathrm{N}$ through the process of retranslocation or the movement of $\mathrm{N}$ from aboveground tissues to belowground tissues prior to autumnal senescence [30-32]. Although studies quantifying $\mathrm{N}$ retranslocation in switchgrass are limited, aboveground biomass $\mathrm{N}$ can be retranslocated and made available for the next growing season $[30,33]$. Recent work on switchgrass grown in Illinois [33] showed that belowground biomass $\mathrm{N}$ stocks nearly doubled from late summer to early autumn, illustrating substantial conservation of $\mathrm{N}$ within the plant. Depending on when retranslocation occurs, the timing of harvest may determine how much $\mathrm{N}$ is removed from the site. For example, Reynolds et al. [30] reported Cave-in-Rock switchgrass harvested in summer contained about $7.5 \mathrm{~g} \mathrm{~kg}^{-1}$ $\mathrm{N}$ in harvested biomass, whereas autumn-harvested switchgrass contained only $3.8 \mathrm{~g} \mathrm{~kg}^{-1} \mathrm{~N}$. If switchgrass is harvested before $\mathrm{N}$ retranslocation is maximized, then $\mathrm{N}$ removal due to harvest will be greater and subsequent crops will require greater fertilizer inputs [34, 35]. Harvesting when senescence is complete allows for maximum $\mathrm{N}$ retranslocation [4]. Other benefits may accrue from harvesting at a later time as well, including reduced ash and moisture content [36] as well as habitat protection for birds of management concern [37].

Nitrogen retranslocation is often cited as a benefit of delaying switchgrass harvest, but quantified $\mathrm{N}$ retranslocation is limited. Understanding seasonal changes in aboveground and belowground $\mathrm{N}$ concentrations will help quantify the ecological importance of $\mathrm{N}$ retranslocation and can enhance management plans and decisions. Our objectives were to (1) quantify the amount of switchgrass $\mathrm{N}$ retranslocation in several environments, (2) estimate the economic value of $\mathrm{N}$ retention due to $\mathrm{N}$ retranslocation, and (3) evaluate economic trade-offs of $\mathrm{N}$ retranslocation to potential crop losses incurred due to delayed harvest.

\section{Methods}

\section{Site Description}

This study was conducted on three managed switchgrass fields (Table 1) to evaluate $\mathrm{N}$ retranslocation in a range of environments. The Pennsylvania (PA) study sites were within a temperate deciduous forest region with about $50 \%$ agricultural land cover. Average temperature at the two PA sites (which are approximately $3 \mathrm{~km}$ apart), is $20.8^{\circ} \mathrm{C}$ in July and
$-4.4{ }^{\circ} \mathrm{C}$ in January. Precipitation is generally greater in summer (June, $11.5 \mathrm{~cm}$ ) than winter (January, $7.2 \mathrm{~cm}$ ). Each PA site was a 10-ha switchgrass seed production field. Soils at the PA sites are Alfisols (38). The PA-1 site was planted to Cavein-Rock in 2000 and contains Frenchtown (Typic Fragiaqualf) and Venango (Aeric Fragiaqualf) silt loam soils. The PA-2 site was planted to Shawnee in 2000 and contains Cambridge (mesic Oxyaquic Fragiudalfs) silt loam soils derived from glacial till. Both PA sites received $45 \mathrm{~kg} \mathrm{ha}^{-1}$ year $^{-1}$ of slow-release N (encapsulated urea) in spring. Herbicides (Paramount ${ }^{\mathbb{B}}(3,7-$ dichloro-8-quinolinecarboxylic acid)) and Stinger ${ }^{\circledR}(3,6$ dichloro-2-pyridinecarboxylic acid, monoethanolamine salt) were applied as needed to control weeds at planting. Switchgrass at the PA sites was mildly infected with smut (Tilletia maclaganii).

The Nebraska (NE) site was a 23-ha bioenergy research field planted to Shawnee in 2006 and managed for biomass production. The site received $50 \mathrm{~kg} \mathrm{~N} \mathrm{ha}^{-1}$ as sulfur-coated urea applied as a single spring application in 2007 and 2008. Herbicides were applied post-planting (560 g a.i.ha ${ }^{-1}$ Quinclorac (3,7-dichloro-8-quinolinecarboxylic acid)) and in July ( $2 \mathrm{~kg}$ a.i. ha ${ }^{-1} 2,4-\mathrm{D}(2,4-$ dichlorophenoxy) acetic acid) in 2006 to control weeds during establishment. Average temperature is $25.4{ }^{\circ} \mathrm{C}$ in July and $-5.4{ }^{\circ} \mathrm{C}$ in January. Precipitation has a distinct seasonal pattern, with higher monthly precipitation in summer (June, $10.8 \mathrm{~cm}$ ) than winter (January, $1.4 \mathrm{~cm}$ ). Soil is a very deep, moderately well-drained, Sharpsburg (Typic Argiudoll) silty clay loam.

Sampling Methods

\section{Biomass}

Biomass was estimated from three $1-\mathrm{m}^{2}$ plots sampled from each field during autumn 2008. The PA sites were sampled in September and the NE site was sampled in early November. Each field was divided into thirds and one plot was sampled randomly from each third. In each plot, standing biomass was divided into two categories, biofuel, which was that material $>10 \mathrm{~cm}$ above the soil surface, and residual biomass, or that material $0-10 \mathrm{~cm}$ above the soil surface. Plant litter (fallen leaves and stems) on the soil surface was collected separately. Plant material was dried at $105^{\circ} \mathrm{C}$ for $48 \mathrm{~h}$.

Belowground biomass was not quantified at the NE site. In the PA sites, belowground biomass was measured to a soil depth of $115 \mathrm{~cm}$ in the $1-\mathrm{m}^{2}$ plots used for aboveground biomass estimation. For the AP horizon, soil surrounding the $1-\mathrm{m}^{2}$ plots was removed to a depth of $50 \mathrm{~cm}$ using shovels and a backhoe and the exposed soil faces were cleaned manually to clearly identify the boundary between the AP horizon ( $\sim 15 \mathrm{~cm}$ in depth) and the B horizon. The entire AP horizon was extracted using a backhoe and shovels. 
Table 1 Description of switchgrass sampling sites in PA and NE

\begin{tabular}{|c|c|c|c|c|c|c|c|}
\hline Site & Location & Elevation (m) & Soils [38] & $\begin{array}{l}\text { Stand age } \\
\text { (year) }\end{array}$ & $\begin{array}{l}\text { Study area } \\
(\mathrm{m})\end{array}$ & $\begin{array}{l}\text { Precipitation } \\
\left(\mathrm{mm}^{-1} \text { yar }^{-1}\right) \\
{[39,40]}\end{array}$ & Fertilizer kg ha ${ }^{-1}$ year $^{-1} \mathrm{~N}$ \\
\hline PA-1 & $\begin{array}{l}41^{\circ} 34^{\prime} \mathrm{N} \\
80^{\circ} 10^{\prime} \mathrm{W}\end{array}$ & 427 & $\begin{array}{l}\text { Alfisol: Venango series and } \\
\text { Frenchtown series silt loams }\end{array}$ & $10-12$ & $200 \times 75$ & 1,120 & 45 \\
\hline PA-2 & $\begin{array}{l}41^{\circ} 33^{\prime} \mathrm{N} \\
80^{\circ} 8^{\prime} \mathrm{W}\end{array}$ & 427 & Alfisol: Cambridge series silt loams & $10-12$ & $300 \times 75$ & 1,120 & 45 \\
\hline $\mathrm{NE}$ & $\begin{array}{l}41.15^{\circ} \mathrm{N} \\
96.40^{\circ} \mathrm{W}\end{array}$ & 366 & $\begin{array}{l}\text { Argiudoll: Sharpsburg series silty } \\
\text { clay loam }\end{array}$ & 3 & $30 \times 30$ & 700 & 0 after est. \\
\hline
\end{tabular}

Roots in the B horizon were collected separately in September and October 2009; three plots were chosen within $10 \mathrm{~m}$ of the location where the AP horizons had been removed in the previous year. The AP horizon was removed first using a backhoe and hand shovels, after which a tarp with a $51-\mathrm{cm}$ diameter hole was placed atop the B horizon. Using a hydraulic soil auger (Bobcat, Inc.) attached to a skid steer loader, a 51-cm diameter hole was excavated through the tarp opening to a depth of $100 \mathrm{~cm}$ below the surface of the B horizon. Soil was extracted from the hole and sieved in a $0.64-\mathrm{cm}$ sieve to separate the roots, which were washed to remove attached soil particles and dried at $105{ }^{\circ} \mathrm{C}$ for $48 \mathrm{~h}$.

\section{Seasonal N Changes}

To examine seasonal changes in tissue $\mathrm{N}$ concentrations, aboveground (AG) and belowground (BG) biomass was collected each month at each site. At the NE site, a $50 \times 50 \mathrm{~m}$ sampling area of the field that was not harvested during fieldscale biomass harvest was divided into four quadrants. At the PA-1 site, a $300 \times 75 \mathrm{~m}$ section of the field was selected for sampling; at the PA-2 site, the sampled section was $200 \times$ $75 \mathrm{~m}$. On the fifteenth ( \pm 2 days) of each month, from June through October 2009, four randomly selected $30 \times 30 \mathrm{~cm}$ samples of switchgrass were collected at each site. Each $30 \times 30 \mathrm{~cm}$ sample typically represented a portion of one switchgrass plant. The aboveground biomass was harvested by hand using pruning shears (PA) or a rice knife (NE). After AG harvest, soil and roots were excavated to a depth of $15 \mathrm{~cm}$. Standing AG biomass sampling in the PA sites ended in October.

Belowground biomass was washed thoroughly by hand with water to remove all attached soil, dried to a constant weight at $105{ }^{\circ} \mathrm{C}$, and sorted into three categories: rhizomes, crown material, and roots. AG biomass was separated into four categories: stems, blades and sheaths, seedheads, and residual (the $10 \mathrm{~cm}$ of stem that remains aboveground after commercial harvesting operations). The AG biomass was dried to a constant weight at $105^{\circ} \mathrm{C}$. These monthly data were used to characterize the growth pattern over the growing season but were not used to quantify biomass at the field scale.
Biomass data are more representative of yield per plant because switchgrass produces dense clumps of approximately the size as the sample area. For $\mathrm{N}$ analyses, subsamples were ground in a Thomas Scientific Wiley Mini-Mill to pass a 0.85-mm screen and analyzed using a Leco CNS-2000 Determinator (St. Joseph, MI, USA).

To track $\mathrm{N}$ concentration in total $\mathrm{AG}$ and total $\mathrm{BG}$ biomass in the $30 \times 30 \mathrm{~cm}$ samples, we aggregated the individual components to obtain total $\mathrm{N}$ for $\mathrm{AG}$ and $\mathrm{BG}$ components. Dividing the total biomass for $\mathrm{AG}$ and $\mathrm{BG}$ components by the total $\mathrm{AG}$ and $\mathrm{BG} \mathrm{N}$ contents yielded average weighted $\mathrm{N}$ concentrations for total AG and BG biomass tissues, respectively, from June through October. To obtain site-level biomass nitrogen estimates, total AG and BG biomass from the $1-\mathrm{m}^{2}$ (2008) plots was multiplied by either the AG or BG weighted N concentrations, respectively. Net $\mathrm{N}$ retranslocation was calculated as the change in total aboveground $\mathrm{N}$ between September and October.

\section{Economic Value of N Retention}

To estimate the economic value of $\mathrm{N}$ retranslocation, we calculated the economic value of $\mathrm{N}$ retained on the site using an $\mathrm{N}$ fertilizer value of $\$ 0.55 \mathrm{~kg}^{-1} \mathrm{~N}$. Fertilizer application costs were not included in the value of retranslocated $\mathrm{N}$ because we assumed that these were fixed costs not influenced strongly by $\mathrm{N}$ rate. To estimate the net economic tradeoff of delaying harvest to maximize $\mathrm{N}$ gains from retranslocation, we first calculated the economic value of $\mathrm{N}$ savings on site due to $\mathrm{N}$ retranslocation and from the retention of $\mathrm{N}$ in biomass that fell upon and remained on site. These savings were then compared to the economic losses resulting from a $10 \%$ loss of harvestable material that might occur if aboveground switchgrass could not be recovered after delayed harvest. To estimate the value of switchgrass biomass, we used a recent sales value of $\$ 88 \mathrm{Mg}^{-1}$.

\section{Statistical Analysis}

Statistical analyses were conducted using SigmaPlot 12.5. One- or two-way analyses of variance (ANOVA) were used 
for parametric data (evaluated via a Shapiro-Wilk normality test) and Kruskal-Wallis ANOVAs on Ranks were used for nonparametric data. Data of unequal variances (tested via an equal variance test) were $\ln$-transformed to produce equal variance. Post hoc analyses were the Holm-Sidak post hoc method for parametric analyses and Dunn's method for nonparametric analyses.

\section{Results}

Biomass

Aboveground biofuel ranged from $9.10 \pm 2.24$ to $13.31 \pm$ $2.32 \mathrm{Mg} \mathrm{ha}^{-1}$ (Table 2) with seasonal changes over the growing season $(p<0.001)$, and peak biomass (Fig. 1) was greater in September $(p<0.001)$ or October $(p=0.002)$ than in June (Holm-Sidak method). For belowground biomass in the PA sites, $12.4 \pm 1.8$ and $15.8 \pm 2.9 \mathrm{Mg} \mathrm{ha}^{-1}$, most of the roots ( 89.4 and $96.7 \%$, respectively) occurred in the AP horizon. Belowground biomass showed no seasonal changes. Litter mass atop this soil surface was similar at the two PA locations, with $3.7 \mathrm{Mg} \mathrm{ha}^{-1}$ at PA-1 and $4.1 \mathrm{Mg} \mathrm{ha}^{-1}$ at PA-2.

All three sites had similar biomass distributions (Fig. 2) in September with stems, blades, and rhizomes generally comprising the majority of the biomass. In aboveground biomass, blades and stems comprised similar proportions of total biomass. In belowground biomass, rhizomes comprised the greatest proportion of biomass for all three environments in September representing $20-31 \%$ of total biomass. Seedheads and residual biomass comprised the smallest biomass components.

\section{Biomass N Concentration}

Nitrogen concentration (Fig. 3) differed significantly among aboveground tissue components $(p<0.001)$. Blades and seedheads were not different from one another but were higher $(p<0.001)$ than the other tissues, which were not different from
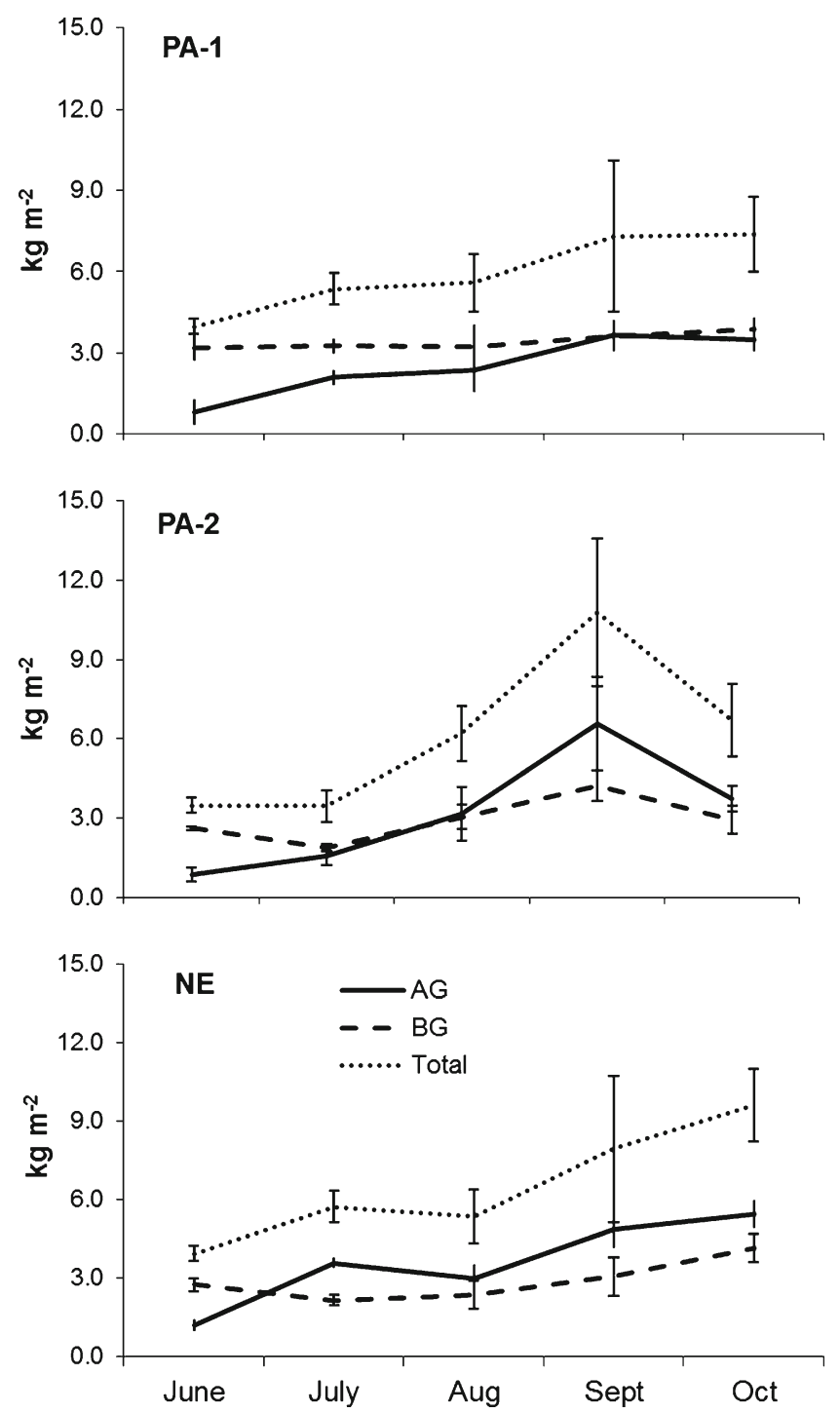

Fig. 1 Aboveground (AG) and belowground (BG) biomass in $30 \times 30 \mathrm{~cm}$ samples collected from three switchgrass fields in Pennsylvania $(P A)$ and Nebraska (NE) in June through October 2009 (bars standard errors)

one another. $\mathrm{N}$ concentrations decreased over the sampling season $(p<0.001)$ with highest values in June in most tissues

Table 2 Late summer biomass (MT ha ${ }^{-1}$ ) for switchgrass sites in PA and NE ( $S E$, standard error)

\begin{tabular}{|c|c|c|c|c|c|c|c|c|c|}
\hline \multirow[b]{2}{*}{ Site } & & \multicolumn{3}{|c|}{$\begin{array}{l}\text { Aboveground (AG) living } \\
\text { mass }\left(\mathrm{MT} \mathrm{ha}^{-1}\right)\end{array}$} & \multirow[t]{2}{*}{$\begin{array}{l}\text { Surface litter } \\
\left(\mathrm{MT} \mathrm{ha}^{-1}\right)\end{array}$} & \multicolumn{3}{|c|}{ Belowground (BG) living mass $\left(\mathrm{MT} \mathrm{ha}^{-1}\right)$} & \multirow[t]{2}{*}{$\begin{array}{l}\text { AG+BG living } \\
\text { biomass (MT ha }\end{array}$} \\
\hline & & Biofuel & Residual & Total & & $\mathrm{AP}$ —horizon roots & B-horizon roots & Total roots & \\
\hline \multirow[t]{2}{*}{ PA-1 } & $\mathrm{x}$ & 13.31 & 1.56 & 14.89 & 3.69 & 15.77 & 0.52 & 16.29 & 31.17 \\
\hline & SE & 2.32 & 0.21 & 2.53 & 1.14 & 2.92 & 0.10 & 3.01 & 4.67 \\
\hline \multirow[t]{2}{*}{ PA-2 } & $\mathrm{x}$ & 9.10 & 1.18 & 10.28 & 4.14 & 12.40 & 1.25 & 13.66 & 23.93 \\
\hline & SE & 2.24 & 0.16 & 2.40 & 0.61 & 1.81 & 0.02 & 1.77 & 3.81 \\
\hline \multirow[t]{2}{*}{$\mathrm{NE}$} & $\mathrm{x}$ & 10.40 & $\mathrm{n} / \mathrm{a}$ & $\mathrm{n} / \mathrm{a}$ & $\mathrm{n} / \mathrm{a}$ & $\mathrm{n} / \mathrm{a}$ & $\mathrm{n} / \mathrm{a}$ & $\mathrm{n} / \mathrm{a}$ & $\mathrm{n} / \mathrm{a}$ \\
\hline & SE & $\mathrm{n} / \mathrm{a}$ & $\mathrm{n} / \mathrm{a}$ & $\mathrm{n} / \mathrm{a}$ & $\mathrm{n} / \mathrm{a}$ & $\mathrm{n} / \mathrm{a}$ & $\mathrm{n} / \mathrm{a}$ & $\mathrm{n} / \mathrm{a}$ & $\mathrm{n} / \mathrm{a}$ \\
\hline
\end{tabular}



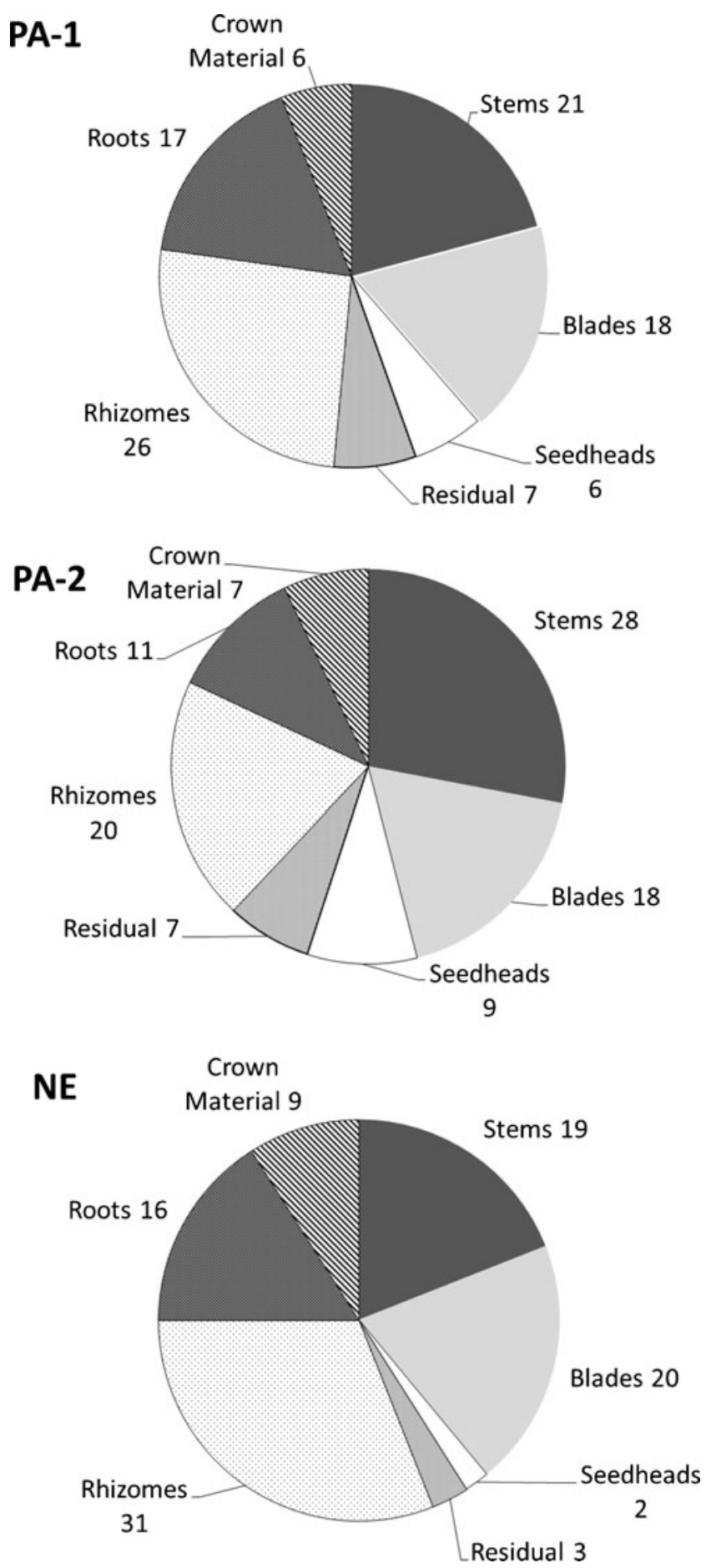

Fig. 2 Mean biomass distribution in three switchgrass fields in Pennsylvania $(P A)$ and Nebraska $(N E)$ in September

decreasing until the postfrost sampling in November. For example, the $\mathrm{N}$ concentration in blades in PA-1 was $21.8 \mathrm{~g} \mathrm{~N} \mathrm{~kg}^{-1}$ in June declining to $6.8 \mathrm{~g} \mathrm{~N} \mathrm{~kg}^{-1}$ in November, a $69 \%$ decrease. Stem N concentrations decreased 77-82 \% among the sites between June and August, after which time little change occurred. Seedheads did not appear at the sites until
July; in the PA sites, seedheads were harvested and removed in late October; hence, there are no data for the PA seedheads for November.

Nitrogen concentrations (Fig. 3) differed among the belowground tissues $(p<0.001)$ and were higher in belowground stems than roots or rhizomes, which were not different from one another. Nitrogen concentration differed among sampling dates $(p<0.001)$. Averaged across the three sites, rhizomes had $\mathrm{N}$ concentrations of $3.8 \mathrm{~g} \mathrm{~N} \mathrm{~kg}^{-1}$ in June and $7.1 \mathrm{~g} \mathrm{~N} \mathrm{~kg}^{-1}$ after the frost in late October.

Weighted $\mathrm{N}$ concentrations in AG tissue (Fig. 4) differed across the season $(p<0.001)$. Across all sites, the aboveground weighted $\mathrm{N}$ concentration was $15.2 \pm 2.5 \mathrm{SE} \mathrm{g} \mathrm{N} \mathrm{kg}^{-1}$ in June, declining to $4.8 \pm 1.2 \mathrm{SE} \mathrm{g} \mathrm{N} \mathrm{kg}^{-1}$ in October. Belowground weighted $\mathrm{N}$ concentrations differed seasonally $(p<0.001)$; concentrations were fairly constant in June and July but increased after August. The weighted $\mathrm{N}$ concentration was $4.2 \pm 0.3 \mathrm{SE} \mathrm{g} \mathrm{N} \mathrm{kg}^{-1}$ in June increasing to $7.1 \pm 1.3 \mathrm{SE} \mathrm{g} \mathrm{N} \mathrm{kg}^{-1}$ in October.

Both aboveground and belowground tissue $\mathrm{N}$ concentrations showed strong and predictable trends over the season. Aboveground $\mathrm{N}$ concentrations of individual tissues were predicted strongly by month, with $r^{2}$ values of blades and seedheads ranging from 0.48 to 0.83 . Relationships between concentration and month were somewhat less predictable in stems and residual material, with $r^{2}$ ranging from 0.13 to 0.93 . For belowground tissues, most $r^{2}$ values exceeded 0.50 . Overall, weighted $\mathrm{N}$ concentrations of $\mathrm{AG}$ and $\mathrm{BG}$ tissue were highly correlated with month, with $r^{2}$ values ranging from 0.82 to 0.89 for aboveground tissues and 0.84 to 0.97 for belowground tissues.

\section{Biomass Nitrogen Content and Retranslocation}

Total aboveground N (Fig. 4) in the $30 \times 30 \mathrm{~cm}$ samples differed seasonally $(p<0.001)$ with values across the sites averaging $0.83 \pm 0.03 \mathrm{~kg} \mathrm{~m}^{-2} \mathrm{~N}$ in June to $4.23 \pm 0.63 \mathrm{~kg} \mathrm{~m}^{-2} \mathrm{~N}$ in October. The NE site had the greatest decrease (42\%) of N in AG tissues from September to October decreasing from 51 to $30 \mathrm{~kg} \mathrm{ha}^{-1}$ (Table 3). PA-1 had the least change in $\mathrm{N}$ in AG tissues from September to October decreasing from 94 to $89 \mathrm{~kg} \mathrm{ha}^{-1}$. Total BG N was not significantly different over the season. Based on net changes in aboveground $\mathrm{N}$ between September and October, the amount of $\mathrm{N}$ retranslocated at the sites ranged from 2.7 to $26.5 \mathrm{~kg} \mathrm{ha}^{-1} \mathrm{~N}$. Across the three sites, $\mathrm{N}$ retranslocation averaged $16.5 \pm 7.1 \mathrm{SE} \mathrm{kg} \mathrm{ha}{ }^{-1} \mathrm{~N}$.

\section{Economic Value of N Retention}

The mean value of switchgrass biomass among the sites $\left(\$ 962.1 \mathrm{ha}^{-1}\right)$ was 2 orders of magnitude greater than the value $\left(\$ 9.6 \mathrm{ha}^{-1}\right)$ of the total amount of retranslocated $\mathrm{N}$ (Table 4). If harvesting is delayed to assure maximum rates 

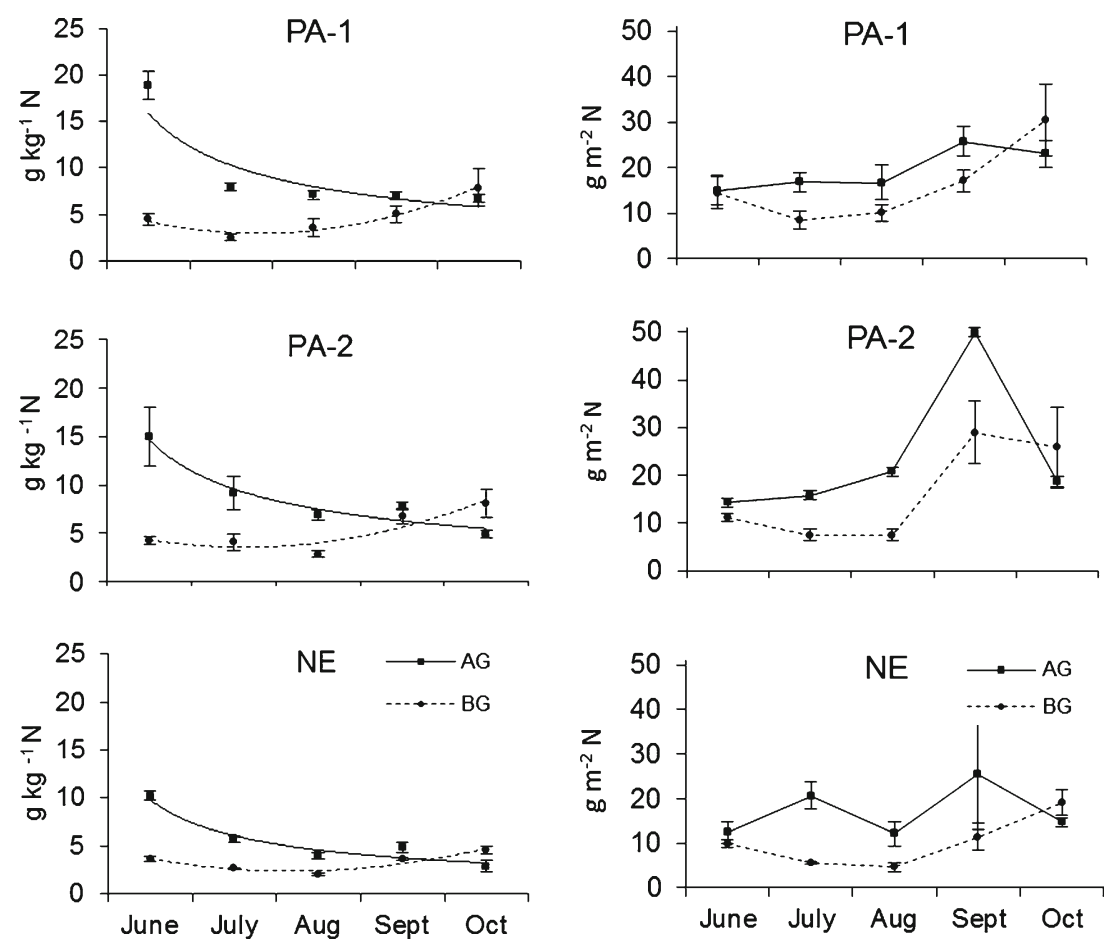

Fig. 3 Nitrogen concentrations of belowground tissues (rhizomes, roots, and crown material) and aboveground tissues (seedheads, stems, blades, residual) in three switchgrass fields in PA and NE sampled from June through November (bars standard errors). BG tissue: $P A-1$ rhizome $[\mathrm{N}]=$ $0.314 x^{2}-0.750 x+3.802, r^{2}=0.88 ; \operatorname{root}[\mathrm{N}]=0.306 x^{2}-1.405 x+4.632, r^{2}$ $=0.93$; crown material $[\mathrm{N}]=0.723 x^{2}-3.847 x+9.41, r^{2}=0.87$. PA-2 rhizome $[\mathrm{N}]=-0.370 x^{3}+3.776 x^{2}-10.133 x+10.991, r^{2}=0.75$; $\operatorname{root}[\mathrm{N}]=$ $-0.165 x^{3}+1.889 x^{2}-5.869 x+8.520, r^{2}=0.96$; crown material $[\mathrm{N}]=$ $-0.499 x^{3}+5.195 x^{2}-15.061 x+17.502, r^{2}=0.85$. NE rhizome $[\mathrm{N}]=$

of $\mathrm{N}$ retranslocation and that delay results in a $10 \%$ harvest loss due to senescing material, then economic gains are offset by a loss of $\$ 96.2 \mathrm{ha}^{-1}$ in the value of material that falls to the ground and is not harvestable. The economic gains include the value of $\mathrm{N}$ that is retranslocated, plus $\mathrm{N}$ in the $10 \%$ of biomass that is not removed in harvest. The loss includes the economic value of biomass that is not harvested. The economic loss in biomass is nearly sevenfold greater than the gains due to $\mathrm{N}$ retranslocation and $\mathrm{N}$ retention combined resulting in a net loss of $\$ 83.9 \mathrm{ha}^{-1}$.

$0.125 x^{2}-0.245 x+3.198, r^{2}=0.70$. Root $[\mathrm{N}]=0.149 x^{2}-0.812 x+3.867$, $r^{2}=0.545$; crown material $[\mathrm{N}]=0.053 x^{2}+0.086 x+3.382, r^{2}=0.38$. AG tissue: $P A-1$ stem $[\mathrm{N}]=9.053 x^{-0.767}, r^{2}=0.59$; blade $[\mathrm{N}]=20.404 x^{-0.519}$, $r^{2}=0.83$. Seedhead $[\mathrm{N}]=12.122 x^{-0.121}, r^{2}=0.133$; residual $[\mathrm{N}]=$ $6.7944 x^{-0.438}, r^{2}=0.27 . P A-2$ stem $[\mathrm{N}]=9.508 x^{-0.843}, r^{2}=0.77$; blade $[\mathrm{N}]=20.592 x^{-0.677}, r^{2}=0.66$; seedhead $[\mathrm{N}]=18.162 x^{-0.317}, r^{2}=0.93$; residual $[\mathrm{N}]=7.3 x^{-0.476}, r^{2}=0.52 . N E$ stem $[\mathrm{N}]=4.479 x^{-0.639}, r^{2}=0.49$; blade $[\mathrm{N}]=13.78 x^{-0.617}, r^{2}=0.58$; seedhead $[\mathrm{N}]=22.006 x^{-0.816}, r^{2}=$ 0.63 ; residual $[\mathrm{N}]=3.220 x^{-0.24}, r^{2}=0.21 . x$ month

Total BG biomass at the PA sites averaged $55 \%$ of the total living biomass with the majority of the root mass concentrated at the soil surface. These results are comparable to those found in other studies. Berdahl et al. [22] found that root biomass was $27 \%$ of the total plant biomass increasing to $84 \%$ when crown tissue (material remaining after roots and aboveground tissue was removed) was included with root biomass. In slight contrast to Berdahl et al. [22], who found that root biomass in the upper $30 \mathrm{~cm}$ of soil comprised 46-49\% of total root mass, we found that most roots were concentrated in the AP horizon, which extends to approximately $15 \mathrm{~cm}$. Although we did not partition soil samples by depth within the B horizon, we observed few roots below the surface of the B horizon. Soils at the PA sites have a high bulk density, particularly below the AP horizon, which likely hinders root extension into deeper soil.

Of the four AG biomass components, blades and stems had Aboveground tissue comprised about $45 \%$ of total biomass and AG blade mass was 33-49\% of total AG biomass. This is consistent with results for Alamo switchgrass in Arkansas [41] where blades represented about one third of total harvested AG biomass. the highest $\mathrm{N}$ concentrations, which is consistent with other studies. Cave-in-Rock grown in Virginia, which had N concentrations of $11.1 \mathrm{~g} \mathrm{~kg}^{-1} \mathrm{~N}$ in July, declined to $5.4 \mathrm{~g} \mathrm{~kg}^{-1} \mathrm{~N}$ in November [34]. In Iowa, Cave-in-Rock AG biomass in 
Fig. 4 Average weighted nitrogen concentration (in kilogram per kilogram $\mathrm{N}$ ) and total $\mathrm{N}$ mass (in gram per square meter $\mathrm{N}$ ) of total aboveground (AG) tissues and total belowground (BG) tissues for three switchgrass fields in PA and NE sampled from $30 \times 30 \mathrm{~cm}$ quadrats from June through October (bars standard errors). Regression lines are superimposed over the monthly data. $P A-1$ AG $[\mathrm{N}]=$ $15.879 x^{-0.623}, r^{2}=0.82 ; \mathrm{BG}[\mathrm{N}]=$ $0.717 x^{2}-3.364 x+6.893$, $r^{2}=0.97 . P A-2 \quad \mathrm{AG}[\mathrm{N}]=$ $14.640 x^{-0.609}, r^{2}=0.89 ; \mathrm{BG}[\mathrm{N}]=$ $0.600 x^{2}-2.562 x+6.297, r^{2}=$ 0.84. NE AG[N] $=9.826 x^{-0.698}$, $r^{2}=0.88 ; \mathrm{BG}[\mathrm{N}]=0.447 x^{2}-$ $2.402 x+5.584, r^{2}=0.88 . x$ month
Belowground
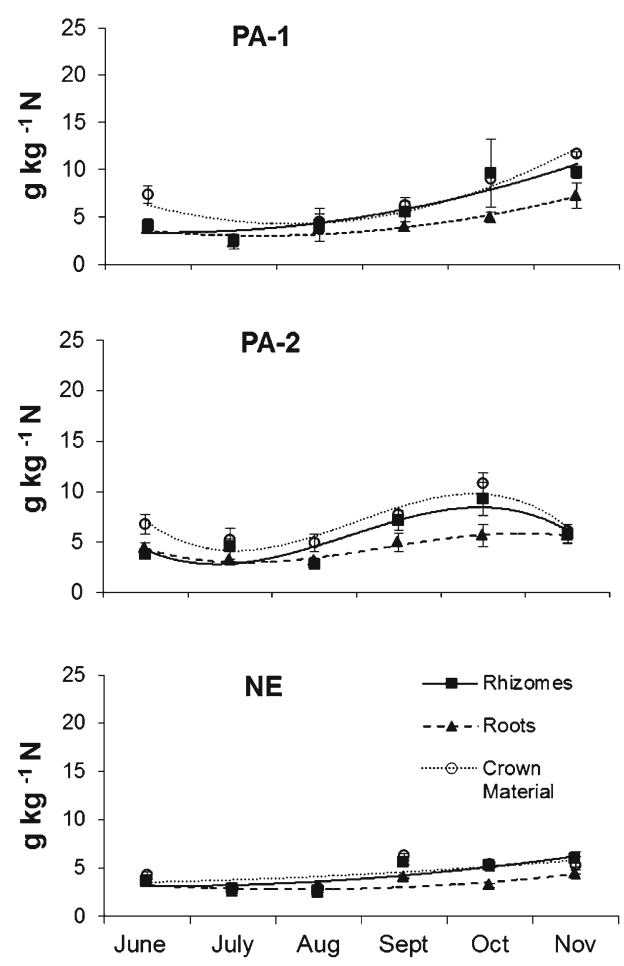

Aboveground

PA-1

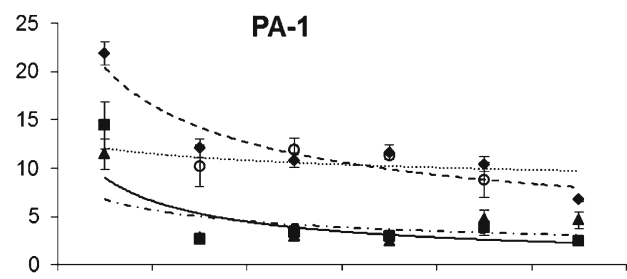

PA-2
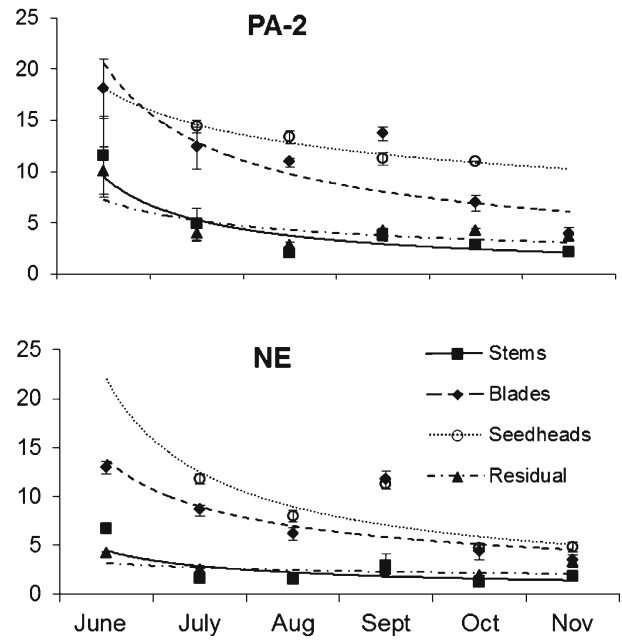

October was $4.2 \mathrm{~g} \mathrm{~kg}^{-1} \mathrm{~N}$ and $\mathrm{BG} \mathrm{N}$ concentration was $9.7 \mathrm{~g} \mathrm{~kg}^{-1} \mathrm{~N}$ [32], comparable to our results. At all three sites, overall AG biomass $\mathrm{N}$ concentrations decreased steadily and were highly correlated with the month of collection. Early in summer, high concentrations are likely due to translocation of $\mathrm{N}$ from roots into $\mathrm{AG}$ tissue, followed by $[\mathrm{N}]$ declines as increases in plant biomass dilute $\mathrm{N}$ concentrations. Later in summer, as biomass stabilizes, $\mathrm{N}$ retranslocation would lead to declines in tissue [N]. Within individual tissue components, the seasonal decrease in $\mathrm{N}$ concentration in switchgrass blades and stems in our study may have been due to both $\mathrm{N}$ movement from these tissues into the seedheads as plants reached maturity $[42,43]$ and retranslocation into BG biomass. In contrast to AG tissue, belowground $\mathrm{N}$ concentrations

Table 3 Aboveground nitrogen and $\mathrm{N}$ retranslocation in switchgrass sites in September and October in PA and NE

\begin{tabular}{|c|c|c|c|c|c|}
\hline \multirow[t]{2}{*}{ Site } & & \multicolumn{2}{|c|}{$\mathrm{kg} \mathrm{ha}^{-1} \mathrm{~N}$} & \multicolumn{2}{|c|}{$\begin{array}{l}\text { Retranslocation between September and } \\
\text { October }\end{array}$} \\
\hline & & $\mathrm{x}$ & SE & $\mathrm{kg} \mathrm{ha}^{-1} \mathrm{~N}$ & $\%$ \\
\hline PA-1 & $\begin{array}{l}\text { Sept } \\
\text { Oct }\end{array}$ & $\begin{array}{l}93.1 \\
90.4\end{array}$ & $\begin{array}{l}5.2 \\
5.3\end{array}$ & -2.7 & -2.9 \\
\hline PA-2 & $\begin{array}{l}\text { Sept } \\
\text { Oct }\end{array}$ & $\begin{array}{l}71.1 \\
44.6\end{array}$ & $\begin{array}{l}3.9 \\
3.8\end{array}$ & -26.5 & -37.2 \\
\hline $\mathrm{NE}$ & $\begin{array}{l}\text { Sept } \\
\text { Oct }\end{array}$ & $\begin{array}{l}50.4 \\
30.0\end{array}$ & $\begin{array}{l}4.4 \\
5.0\end{array}$ & -20.4 & -40.5 \\
\hline
\end{tabular}

increased over the season with the lowest values in early summer and peak concentrations in autumn.

Table 4 Economic trade-offs between nitrogen savings due to $\mathrm{N}$ retranslocation and economic losses due to biomass loss in switchgrass sites (nitrogen fertilizer, $\$ 0.55 \mathrm{~kg}^{-1} \mathrm{~N}$; switchgrass market value, $\left.\$ 88 \mathrm{Mg}^{-1}\right)$

\begin{tabular}{|c|c|c|c|c|c|}
\hline & & \multicolumn{4}{|c|}{ Harvest loss rate $(\%)$} \\
\hline & & \multicolumn{2}{|l|}{0} & \multicolumn{2}{|l|}{10} \\
\hline & & $\mathrm{x}$ & SE & $\mathrm{x}$ & SE \\
\hline Potential biomass harvest & $\mathrm{Mg} \mathrm{ha}^{-1}$ & 10.9 & 1.2 & 9.9 & 1.1 \\
\hline Biomass harvest value & $\$ \mathrm{ha}^{-1}$ & 962.1 & 109.2 & 868.3 & 98.7 \\
\hline Biomass economic loss & $\$ \mathrm{ha}^{-1}$ & 0.0 & 0.0 & 96.2 & 10.9 \\
\hline $\mathrm{N}$ retranslocated & $\mathrm{kg} \mathrm{ha}^{-1}$ & 16.5 & 7.1 & 16.5 & 7.1 \\
\hline $\begin{array}{l}\text { Economic value of } \\
\text { retranslocated } \mathrm{N}\end{array}$ & $\$ \mathrm{ha}^{-1}$ & 9.1 & 3.9 & 9.1 & 3.9 \\
\hline $\begin{array}{l}\mathrm{N} \text { retained on site in } \\
\text { fallen biomass }\end{array}$ & $\mathrm{kg} \mathrm{ha}^{-1}$ & 0.0 & 0.0 & 5.4 & 1.8 \\
\hline $\begin{array}{l}\text { Economic value of } \mathrm{N} \\
\text { retained in fallen biomass }\end{array}$ & $\$ \mathrm{ha}^{-1}$ & 0.0 & 0.0 & 3.0 & 1.0 \\
\hline $\begin{array}{l}\text { Total } \mathrm{N} \text { retained } \\
\text { (retranslocation }+\mathrm{N} \text { in } \\
\text { fallen biomass) }\end{array}$ & $\mathrm{kg} \mathrm{ha}^{-1}$ & 16.5 & 7.1 & 21.9 & 5.6 \\
\hline $\begin{array}{l}\text { Value of } \mathrm{N} \text { retained } \\
\text { (retranslocation }+\mathrm{N} \text { in } \\
\text { fallen biomass) }\end{array}$ & $\$ \mathrm{ha}^{-1}$ & 9.1 & 3.9 & 12.3 & 3.1 \\
\hline $\begin{array}{l}\text { Net economic impact } \\
\text { ( } \mathrm{N} \text { retained-biomass loss) }\end{array}$ & $\$ \mathrm{ha}^{-1}$ & 9.1 & 3.9 & -83.9 & 14.1 \\
\hline
\end{tabular}


Biomass N Quantity and Retranslocation

At all the sites, total $\mathrm{N}$ in $\mathrm{AG}$ tissues increased between August and September; this increase seems to be largely in the blades, which had higher $\mathrm{N}$ concentrations than the stems and which comprised a large proportion of the AG biomass (Figs. 2 and 3). Additionally, AG biomass increased between August and September at PA-2 and NE (Fig. 1) suggesting additional $\mathrm{N}$ uptake from soil into living tissue. From August to September, blade $\mathrm{N}$ concentrations increased indicating that plants were still actively taking up soil $\mathrm{N}$ or perhaps that roots were transferring tissue-bound $\mathrm{N}$ from distal belowground locations. Given the low amount of root mass below the AP horizon, however, this does not seem likely in PA. Quantifying plant $\mathrm{N}$ origin is complicated because plants use $\mathrm{N}$ from multiple sources, including both soil and plant tissue storage $[25,30,32]$.

Examination of net changes in total $\mathrm{AG}$ and $\mathrm{BG}$ biomass $\mathrm{N}$ reveals movement from $\mathrm{AG}$ to $\mathrm{BG}$ tissues; $\mathrm{AG}$ weightedaverage $\mathrm{N}$ concentrations among the sites declined between 2.9 and $40.5 \%$ between September and the time of senescence in October. The mean $\mathrm{N}$ retranslocation rate across the sites was $16.5( \pm 7.1 \mathrm{SE}) \mathrm{kg} \mathrm{ha}^{-1} \mathrm{~N}$ comparable to rates reported for switchgrass grown in Illinois, where AG biomass declined from 16.5 to $5 \mathrm{~g} \mathrm{~kg}^{-1} \mathrm{~N}$ between June and December [33]. We observed a tenfold range in rates among our sites from $2.7 \mathrm{~kg} \mathrm{ha}^{-1} \mathrm{~N}$ at PA-1 to $26.7 \mathrm{~kg} \mathrm{ha}^{-1} \mathrm{~N}$ at the NE site (Table 4). The PA-1 site was more productive than the other sites suggesting a possible correlation between site productivity and movement of AG N to BG tissues at the end of the season, although the relationship between soil $\mathrm{N}$ availability and $\mathrm{N}$ retranslocation rates is not clear. Reviews of the literature across many tree species [44-47] and grasses [48] show that increased soil $\mathrm{N}$ availability reduces retranslocation rates even within the same species. However, those same studies also document that rates of $\mathrm{N}$ retranslocation are either independent from or not strongly controlled by rates of $\mathrm{N}$ availability. Stand age may play a role in determining rates; however, the NE site, which was 3 years old, and PA-2, at 9 years old, had comparable $\mathrm{N}$ retranslocation rates.

\section{Economics of N Retention vs. Harvest Losses}

Nitrogen retranslocation, $16.5( \pm 7.1 \mathrm{SE}) \mathrm{kg} \mathrm{ha}^{-1} \mathrm{~N}$, represented $26.7 \%$ of the average maximum $\mathrm{N}$ content of $\mathrm{AG}$ biomass and thus provides a substantial source satisfying annual switchgrass $\mathrm{N}$ requirements. If biomass harvest is delayed until retranslocation is complete, then this process conserves a large portion of the annual plant needs within the BG tissue. Expressing this $\mathrm{N}$ quantity in economic terms, on average, this provides an economic value of $\$ 9.1 \mathrm{ha}^{-1}$ (Table 4). However, if harvesting is delayed such that oncoming winter conditions result in a $10 \%$ loss of total standing biomass, then the economic losses due to lost biomass are more than fourfold greater than the combined value of the economic gains from $\mathrm{N}$ retained by retranslocation and in the $\mathrm{N}$ contained in biomass that remains upon the site. We have observed that blades and seeds are the first tissue components to fall from the plants in late autumn. These tissues have much higher $\mathrm{N}$ concentrations than the stems and together they constitute $49-54 \%$ of the total aboveground biomass. Loss of these tissues can provide an $\mathrm{N}$ return to soil due to their high $\mathrm{N}$ concentrations, but they are at the greatest risk of being lost from harvestable biomass. Previous work has shown that harvesting an overwintered switchgrass crop in spring resulted in a $20-24 \%$ loss of yield, increasing to $40 \%$ after an especially snowy winter [36]. Long delays in harvesting, however, are not necessary to obtain the benefits related to $\mathrm{N}$ retranslocation. Heaton et al. [49] found little change in $\mathrm{N}$ removal between an early winter harvest and a late winter harvest in Illinois indicating that harvesting after the $A G$ portion of the plant is no longer physiologically active (usually the first killing frost in cold regions) will allow for the greatest transfer of $\mathrm{N}$ from $\mathrm{AG}$ to $\mathrm{BG}$ tissues.

Timing of biomass harvest is dictated by many factors besides $\mathrm{N}$ retranslocation and product loss, including local weather and soil conditions, wildlife habitat requirements, weed pressure, water and ash content, and market conditions. Additionally, biochemical and thermochemical conversion platforms have different optimum feedstock characteristics that may dictate the maturity stage of optimal feedstock harvest [50]. Nonetheless, to maximize $\mathrm{N}$ retranslocation and minimize harvest loss, it would be optimal to harvest switchgrass as soon as possible after complete senescence.

Acknowledgements We greatly appreciate the logistical and field support of Calvin Ernst, Mark Fiely, Evan Cross, and Greg Kedzierski of Ernst Conservation Seeds and invaluable laboratory assistance from Sam Reese, Alessandro Trunzo, and Taylor Weiss. This work was supported by an Allegheny College Shanbrom Research Fund grant to Wayman.

\section{References}

1. Kszos LA, McLaughlin SB (2005) Development of switchgrass (Panicum virgatum) as a bioenergy feedstock in the United States. Biom Bioen 28:515-535

2. Schmer MR, Vogel KP, Mitchell RB, Perrin RK (2008) Net energy of cellulosic ethanol from switchgrass. PNAS 105:464-469

3. Solomon BR (2010) Biofuels and sustainability. Ann New York Acad Sci 1185:119-134

4. Beringer T, Lucht W, Schaphoff S (2011) Bioenergy production potential of global biomass plantations under environmental and agricultural constraints. Glob Chang Bio Bioenergy 3:299-312

5. Vogel KP, Brejda JJ, Walters DT, Buxton DR (2002) Switchgrass biomass production in the midwest USA: harvest and nitrogen management. Agron J 94:413-420 
6. Fazio S, Monti S (2011) Life cycle assessment of different bioenergy production systems including perennial and annual crops. Biom Bioen 35:4868-4878

7. Varvel GE, Vogel KP, Mitchell RB, Follett RN, Kimble JM (2007) Comparison of corn and switchgrass on marginal soils for bioenergy. Biom Bioen 32:18-21

8. Smeets EMW, Lewandowski IM, Faaij APC (2009) The economical and environmental performance of Miscanthus and switchgrass production and supply chains in a European setting. Renew Sustain Energ Rev 13:1230-1245

9. Dale V, Kline K, Wright LL, Perlack RD, Dowing M, Graham R (2011) Interactions among bioenergy feedstock choices, landscape dynamics, and land use. Ecol Appl 21:1039-1054

10. Hartman JC, Nipperta JB, Orozcob RA, Springer CJ (2011) Potential ecological impacts of switchgrass (Panicum virgatum L.) biofuel cultivation in the Central Great Plains, USA. Biom Bioen 35:3415-3421

11. Weaver JE, Zink E (1946) Length of life of roots of ten species of perennial range and pasture grasses. Plant Phys 21:201-217

12. Parrish DJ, Fike JH (2005) The biology and agronomy of switchgrass for biofuels. Crit Reviews Plant Sci 24:423-459

13. Bingham L, Green TH, Mays DA, Nyakatawa EZ, Tolbert VR (2006) Runoff, sediment, nitrogen, and phosphorus losses from agricultural land converted to sweetgum and switchgrass bioenergy feedstock production in North Alabama. Biom Bioen 30:655-664

14. Isenhart TM, Lee KH, Schultz RC (2003) Sediment and nutrient removal in an established multi-species riparian buffer. J Soil Wat Cons 1:1-8

15. Liu S, Yiping W (2012) Impacts of biofuels production alternatives on water quantity and quality in the Iowa River Basin. Biom Bioen 36:182-191

16. Liebig MA, Schmer MR, Vogel KP, Mitchell RB (2008) Soil carbon storage by switchgrass grown for bioenergy. Bioenergy Research 1:215-222

17. Liebig MA, Johnson HA, Hanson JD, Frank AB (2005) Soil carbon under switchgrass stands and cultivated cropland. Biom Bioen 28:347-354

18. Alva AK, Collins HP, Fransen S, Granatstein DM, Kruger CE, Smith JL (2010) Carbon sequestration under irrigated switchgrass (Panicum virgatum L.) production. Soil Sci Soc Am J 74:2049-2058

19. Ma Z, Wood CW, Bransby DI (2000) Soil management effects on soil carbon sequestration by switchgrass. Biom Bioen 18:469-477

20. Jung JY, Lal R (2011) Impacts of nitrogen fertilization on biomass production of switchgrass (Panicum virgatum $\mathrm{L}$.) and changes in soil organic carbon in Ohio. Geoderma 166:145-152

21. Zeria M, Anderson-Teixeira K, Hickman G, Masters M, DeLucia E, Bernacchi CJ (2011) Carbon exchange by establishing biofuel crops in Central Illinois. Agri Eco Env 144:319-329

22. Berdahl JD, Frank AB, Hanson JD, Johnson HA, Leibig MA (2004) Biomass and carbon partitioning in switchgrass. Crop Sci 44:13911396

23. Ma Z, Wood CW, Bransby DI (2000) Impacts of soil management on root characteristics of switchgrass. Biom Bioen 18:105-112

24. Garten CT, Brice DJ, Castro HF, Graham RL, Mayes MA, Phillips JR, Post WM, Schadt CW, Wullschleger SD, Tyler DD, Jardine PM, Jastrow JD, Matamala R, Miller RM, Moran KK, Vugteveen TW, Izaurralde RC, Thomson AM, West TO, Amonette JE, Bailey VL, Metting FB, Smith JL (2011) Response of "Alamo" switchgrass tissue chemistry and biomass to nitrogen fertilization in West Tennessee USA. Agri Eco Env 140:289-297

25. Lemus RW, Brummer EC, Burras CL, Moore KJ, Barker MF, Molstad NE (2008) Effects of nitrogen fertilization on biomass yield and quality in large fields of established switchgrass in Southern Iowa, USA. Biom Bioen 32:1187-1194

26. Sarkara S, Miller SA, Frederick JR, Chamberlain JF (2011) Modeling nitrogen loss from switchgrass agricultural systems. Biom Bioen $35: 4381-4389$
27. Kapp CJ, Min DH, Nikiema P, Rothstein DE (2011) Nitrogen fertilization of switchgrass increases biomass yield and improves net greenhouse gas balance in Northern Michigan, U.S.A. Biom Bioen 35:4356-4367

28. Perrin R, Vogel K, Schmer M, Mitchell R (2008) Farm-scale production cost of switchgrass for biomass. Bioenerg Res 1:91-97

29. Smith KA, Searchinger TD (2012) Crop-based biofuels and associated environmental concerns. Global Change Biology Bioenergy 4:479-484

30. Reynolds JH, Walker CL, Kirchner MJ (2000) Nitrogen removal in switchgrass biomass under two harvest systems. Biom Bioen 19:281-286

31. Heckathorn SA, DeLucia EH (1994) Drought-induced nitrogen retranslocation in perennial $\mathrm{C} 4$ grasses of tallgrass prairie. Ecology 75:1877-1886

32. Heggenstaller AH, Moore KJ, Liebman M, Anex RP (2009) Nitrogen influences biomass and nutrient partitioning by perennial, warmseason grasses. Agron J 101:1363-1371

33. Dohleman FG, Heaton EA, Arundale RA, Long SL (2012) Seasonal dynamics of above- and below-ground biomass and nitrogen partitioning in Miscanthus giganteus and Panicum virgatum across three growing seasons. Global Change Biology Bioenergy 4:534-544

34. Lemus R, Parrish DJ, Abaye O (2008) Nitrogen-use dynamics in switchgrass grown for biomass. Bioenergy Research 1:153-162

35. Owensby CE, Rains JR, McKendrick JD (1974) Effects of one year of intensive clipping on Big Bluestem. J Range Manage 27:341-343

36. Sample DW, Ribic CA, Paine L, Undersander D, Bartelt GA (2005) Grassland bird response to harvesting switchgrass as a biomass energy crop. Biom Bioen 28:490-498

37. Adler PR, Sanderson MA (2006) Biomass yield and biofuel quality of switchgrass harvested in autumn or spring. Agron J 98:1518-1525

38. Soil Survey Staff, Natural Resources Conservation Service, United States Department of Agriculture. Official soil series descriptions. USDA-NRCS, Lincoln, NE. http://soils.usda.gov/technical/ classification/osd/index.html. Accessed 14 Jan 2011.

39. City-Data.com (2009) FAA registered airports and heliports in Meadville, PA. http://www.city-data.com/airports/Meadville-PA. html. Accessed Oct 2010

40. City-Data.com (2009) Wahoo, NE. http://www.city-data.com/city/ Wahoo-Nebraska.html. Accessed Oct 2010

41. Schmer MR, Mitchell RB, Vogel KP, Schacht WH, Marx DB (2010) Spatial and temporal effects on switchgrass yield in the great plains. Bioenergy Res 3:159-171

42. Dordas CA, Sioulas C (2009) Dry matter and nitrogen accumulation, partitioning, and retranslocation in safflower (Carthamus tinctorius L.) as affected by nitrogen fertilization. Field Crops Res 110:35-43

43. Dordas CA (2009) Dry matter, nitrogen and phosphorus accumulation, partitioning and remobilization as affected by $\mathrm{N}$ and P fertilization and source-sink relations. Eur J Agron 30:129 139

44. Aerts R (1996) Nutrient resorption from senescing leaves of perennials: are there general patterns? J Ecology 84:597-608

45. Killingbeck K (1996) Nutrients in senesced leaves: keys to the search for potential resorption and resorption proficiency. Ecology 77:1716-1727

46. Norris MD, Reich PD (2009) Modest enhancement of nitrogen conservation via retranslocation in response to gradients in $\mathrm{N}$ supply and leaf N status. Plant Soil 316:193-204

47. Xuefeng L, Xingbo Z, Shijie H, Tonghua L (2010) Effects of nitrogen additions on nitrogen resorption and use efficiencies and foliar litterfall of six tree species in a mixed birch and poplar forest, northeastern China. Can J Forest Res 40:22562261

48. Han XG, Lu XT (2012) Nutrient resorption responses to water and nitrogen amendment in semi-arid grassland of Inner Mongolia, China. Plant Soil 327:481-491 
49. Heaton EA, Dohleman FG, Long SP (2009) Seasonal nitrogen dynamics of Miscanthus $x$ giganteus and Panicum virgatum. Global Change Biology Bioenergy 1:297-307
50. Mitchell RB, Schmer MR (2012) Switchgrass harvest and storage. In: Monti A (ed) Switchgrass, green energy and technology. Springer, London, pp 113-127 